INTERNATIONAL JOURNAL OF RESEARCHES IN BIOSCIENCES, AGRICULTURE AND TECHNOLOGY (C) VISHWASHANTI MULTIPURPOSE SOCIETY (Global Peace Multipurpose Society) R. No. MH-659/13(N) www.vmsindia.org

\title{
ASSESSMENT OF BONE MINERALS OF YOUNG CHICKS FED WITH SUPPLEMENTARY MOLLUSCAN DIET ALONG WITH CONVENTIONAL FOOD
}

\author{
S. R. Akarte and R. B. Bahadure \\ Department of Zoology, Vidyabharati Mahavidyalaya, \\ C.K.Naidu Road, Camp, Amravati (M.S.) India. \\ srakarte@rediffmail.com
}

\begin{abstract}
:
Poultry diet is composed mixture of various conventional feedstuffs such as cereal grains, soybean meal, various animal by-product meals, fats, vitamin and mineral mixture including some trace minerals. The nutritionists try to develop diets, which maximize chick growth and research interest has therefore, been awakened in the area of alternative feed resources which have comparative nutritive value in growth and structural development. Skeletal abnormalities including an increase in bone mass represent a big concern within the poultry industry as it causes considerable production problems. So the experimental attempt had been undertaken to assess the effect of supplementary diet of shell crush and dried flesh of bivalve mollusk added to conventional poultry feed in respect to digestibility and utilization of this diet fed to young chicks. Considering the bioavailability and utilization of this diet with respect to bone strength and the presence or absorption of essential minerals such calcium and phosphorus, sodium and potassium in the bones of the chicks fed with supplementary molluscan diet were estimated. This study was conducted to establish the nutritive value of true metabolizable energy, apparent metabolizable energy and body composition. It was observed that our supplementary feed is easily accepted by the all experimental and control chicks without any abnormality in skeletal development and bone strength Keywords: Molluscan feed, Chicks, Bone minerals.
\end{abstract}

\section{Introduction:}

Some experimental studies show formulation of feed for poultry birds is important through practical point of view in order to provide high quality proteins of animal origin for animal nutrition particularly for poultry birds. Animal protein supplements like bone meal is a good source of calcium and phosphorus, but invariably additional sources of calcium and phosphorus like molluscan feed added to meet the nutrient requirements along with conventional feed can also prove as supplementary diet for poultry birds. So the present study was undertaken to assess the effect of addition of molluscan dried flesh and shell crush in different components of normal conventional grains, containing Bajara, wheat, rice bran, maize, pea beans, sorghum, etc. as feed for chicks. This study focuses on any benefits on growth, strength and minerals contents of bone after feeding chicks with supplementary molluscan diet at early developmental period of chicks

\section{Material and Methods-}

The bivalve mollusc, Lamellidens marginalis, were collected from local lakes and kept in deep freeze to sacrifice without any loss of nutrient contents of it. Then the whole body was separated out from shell, superficially blotted with filter paper, dried in oven completely. The animal shell crush and dried flesh was blended in grinder to prepare supplementary molluscan diet. This mixture was added to grinded grains so that $10 \%$ and

$20 \%$ will be the content of it in the total feed. The pellets of this grinded mixture after slight soaking in water were prepared for easy pecking by chicks. The one day old poultry birds were collected from poultry farm, acclimatized for rearing in the laboratory conditions for 3 days and then divided into 5 different groups. These chicks were fed for one month as Control group I- fed with only grains, Group II fed with only poultry farm recognized food, Group III fed with $10 \%$ molluscan feed added to grains, Group IV fed with $20 \%$ molluscan feed added to grains, Group V fed with $10 \%$ fish meal added to grains. The diet was provided ad libitum with water. After sacrificing, the chick's bone ash was prepared in Muffle Furnace at 500-550 ${ }^{\circ} \mathrm{C}$. Ash was cooled and then proceeded for determination of sodium, potassium and calcium by Digital Flame Photometer and phosphorus by UV-VIS, reffering Sudharmai Devi, (2004) method.

\section{Result and Discussion:}

There is a need for better understanding of bone strength in poultry because bone breakage and associated infections contribute to mortality, low productivity, and carcass condemnations. Bone weakness and other bone problems also constitute significant animal welfare issues because of lameness and 
mortalities stemming from leg weakness and osteoporosis in laying hens (Aziz-Abdul, 1998).

It is widely known that problems associated with abnormalities in skeleton development, such as tibiotarsal rotation, reduce the young chick's resilience and increase the likelihood of its premature death and/or failure to meet production requirements. Skeletal disorders are more pronounced in fastgrowing birds. Calcium, phosphorus and magnesium metabolis $m$ disorder is one of the recognized causes of skeletal development problems. Normal bone development in birds is influenced by nutritional factors, genetics, gender and the absolute growth rate.

A number of invasive (bone ash, breaking strength, weight and bone volume) and noninvasive methods (ultrasound) exist to determine the bone mineralization in poultry (Onyango et al., 2003). A high correlation was especially noted between bone mineral content and bone ash weight. These results show that densitometry accurately measures differences in bone mineral densities and bone mineral content in live birds fed with svarying concentrations of dietary calcium is reported by Schreiweis et al., 2003a. According to Almeida $\mathrm{Paz}$ and Bruno, (2006), femur suffer more changes in bone mineral density during lay in broiler breeders, which suggests that this bone is able to provide calcium more easily for maintaining mineral homeostasis. However, when bird requirement increases, the tibia is the main bone supplying this requirement.

A complex array of factors that include structural, architectural, compositional, physiological and nutritional factors interactively determine bone quality and strength. Some of the major factors that affect bone strength are antinutrients. These are various biotic and abiotic factors that affect bone growth, metabolism and matrix constituents, thereby affecting bone strength. Lathyritic agent $\beta$-aminopropionitrile of certain sweet peas inhibits the enzyme lysyl oxidase, preventing collagen crosslinks and mineralization, which decreases bone strength (Seigel and Fu, 1976). Mycotoxin-contaminated diets can affect growth and cause bone fragility and decrease bone strength (Huff et al., 1980; Maurice et al., 1983). Many antinutrients such as mycotoxins affect bone strength indirectly by affecting the metabolism of factors such as vitamin $\mathrm{D}$ that are essential for bone health (Duff et al., 1987).

The role of nutritional factors is probably most relevant to poultry bone strength.
There are many studies of Calcium and Phosphorus that provide the basis for specific recommendations by the National Research Council (1994) for dietary Calcium and Phosphorus in broilers, breeders and layers. Calcium homeostasis is an important driving force in the maintenance of bone strength. Low Ca stimulates secretion of parathyroid hormone and vitamin $\mathrm{D}$ synthesis, which in turn activate release of bone minerals. Therefore, adequate $\mathrm{Ca}$ is necessary to decrease bone turnover. In poultry management, Ca deficiency does not seem to be a problem. However, there can be problems of malabsorption that can impair intestinal Ca absorption (Perry et al., 1991).

The balance between calcium and phosphorus is very important to bone tissue formation because the mobilization and deposition of these minerals can modify the bone mass (Pizauro Junior, 2002). The phosphorus deposition at bone is synchronized with calcium deposition because these minerals form an insoluble salt (Dell'Isola et al., 2003). Considering this the evaluation of phosphorus, calcium, sodium and potassium content in the bones of chick was done after feeding them for one month with supplementary molluscan diet. The estimated phosphorus content from the bones of experimental chick was $0.07 \pm 0.0018(\mathrm{mg} / \mathrm{gm})$ in group $-1,0.14 \pm 0.002 \mathrm{mg} / \mathrm{gm}(\mathrm{P}<0.01)$ in group- $2,0.1 \pm 0.0016 \mathrm{mg} / \mathrm{gm}(\mathrm{P}<0.01)$ in group$3,0.15 \pm 0.004 \mathrm{mg} / \mathrm{gm}(\mathrm{P}<0.01)$ in group -4 , and $0.01 \pm 0.003 \mathrm{mg} / \mathrm{gm}(\mathrm{P}<0.01)$ in group-5. It is observed that the phosphorus level of bone in experimental chicks was highest in group-4 fed with $20 \%$ molluscan feed and slightly lower in chicks fed with $10 \%$ molluscan feed chicks than chicks supplied with commercial food, but comparatively it was more in both the molluscan fed groups than that of only grain fed chicks, whereas it was quiet less in fishmeal fed chicks compared to all the groups. The higher calcium and phosphorus content of the bones without any deformities suggest the optimum absorption of molluscan diet for growth and development of strong skeleton providing support to muscular development, as it was also reported by Lilburn, (1994). Korver et al., (2004) that the rapid growth rate of poultry birds has resulted in the potential for skeletal development. It was determined by assessing bone mineral density in vivo.

The contents of calcium in bones of experimental chicks was $0.03 \pm 0.003(\mathrm{mg} / \mathrm{gm})$ in group- $1,0.06 \pm 0.0025 \mathrm{mg} / \mathrm{gm}(\mathrm{P}<0.01)$ in group- $2,0.07 \pm 0.003 \mathrm{mg} / \mathrm{gm}(\mathrm{P}<0.01)$ in group$3,0.1 \pm 0.003 \mathrm{mg} / \mathrm{gm}(\mathrm{P}<0.01)$ in group -4 , and 
$0.03 \pm 0.003 \mathrm{mg} / \mathrm{gm}$ (NS) in group-5. These contents showed that the calcium level in bones of was highest in chicks fed with $20 \%$ molluscan feed and slightly less than it is $10 \%$ molluscan fed chicks and in chicks fed with poultry feed recognized feed, whereas it was quite less in chicks fed with white grain and fish meal feed. It is obvious because it is well known that the calcium content is more in mollucan shell which is absorbed in bones of molluscan diet fed chicks, but no adverse effect was recorded in development of bones these chicks. It is reported that Calcium carbonate is responsible for the scleratization of the exoskeleton and represents most of the mineral matter of shrimp waste meal which was fed as partially or totally replaced soybean meal in broiler ration, as one of the unconventional protein sources of animal origin, with a good potential (Rosenfeld et al., 1997). It is also considered that increasing Calcium levels consistently reduce leg abnormalities. In the present experiment no abnormalities in legs of the developing chicks was observed and no symptom of scleratization (any hardness) was seen. Though the contents of calcium was more in molluscan fed chicks than that of other groups, movements of these chicks was normal indicating the complete utilization and calcium content in diet and no over-crossing of calcium level. The behavior and postural activity of chicks which are suppose to be affected due to of calcium content of shell, but all experimental chicks were normal and showed normal movements. It is advised that no oyster shell crush should be provided with food content, but it $\mathrm{s}$ also opined that it acts as grit in crop and helps to churn the food content. In our feeding experiment no denial or reduction in feed intake by chicks was observed and also our other studies of histological and histochemical observation of crop showed no cellular damage.

Supplemental protein and carbohydrate as energy sources are also important for bone health. However, excess protein intake can produce negative $\mathrm{Ca}$ balance and stunt bone growth (Heany, 1998). Therefore, supplemental $\mathrm{Ca}$ with protein may be necessary to maintain optimal Ca balance and bone health. Similarly, diets consisting of highly saturated fats can have an adverse effect on bone mineralization, and low-fat diets can increase cancellous bone strength and bone mineral content (Wohl et al., 1998). Ziaei et al., (2010) determined the effect of three levels of crude protein and three levels of $\mathrm{Ca}$ and available $\mathrm{P}$ (as per national research council advice, $15 \%$ more and $15 \%$ less than national research council advise) on performance of broilers after hatching until 21 days of age. They observed reducing crude protein, $\mathrm{Ca}$ and available $\mathrm{P}$ content of the diet significantly increased $\mathrm{P}, \mathrm{Ca}$ and $\mathrm{N}$ retention, whereas reduce in crude protein content of the diet led to a decrease in length, Phosphorus and tibia bone ash.

Edwards and Veltmann, determined calcium and phosphorus levels in the diet as major nutrient factors influencing the expression of tibial dyschondroplasia. The incidence of tibial dyschondroplasia was not apparently correlated with rate of growth, efficiency of feed utilization or bone ash, but the higher levels of calcium and phosphorus in the ration are of great importance in preventing tibial dyschondroplasia and development of the lesion in broilers. In our experiment, content of phosphorus was less in excreta and blood serum whereas it was more in bones suggesting more absorption of phosphorus as required for bone development and lower value in serum and excreta indicates the utilization of it in functional metabolism claiming its bioavailability. It was also observed that feed intake, the behavior and quality of fecal matter was normal without any apparent abnormality in leg indicating the proper metabolism of food intake

Heuser's (1952) study with chicks up to eight weeks of age showed the minimum salt requirement to be $0.65 \%$ of the diet and McWard and Scott, (1961) with purified diets found the sodium requirement of the chick, up to 4 weeks of age is equivalent of $0.28 \%$ to $0.50 \%$ sodium chloride in the diet. Kumpost and Sullivan (1966) determined that a level of $0.15 \%$ to $0.2 \%$ sodium in the diet was required for turkeys up to four weeks of age for maximum gain and feed efficiency. It also found that a level of $0.4 \%$ sodium chloride was required in a corn-soybean meal diet containing no ingredients of animal origin. The scientists also reported an interaction between sodium and potassium and suggested an optimum ration of about 2 to 2.5 parts potassium to one part sodium in young turkey diets. From our experimental chicks sodium and potassium contents bones was estimated to know any over deposition of it due to molluscan diet compared to other feed..

The sodium content in bones of chicks was found as $0.1 \pm 0.0012(\mathrm{mg} / \mathrm{gm})$ in group- $1,0.2$ $\pm 0.002 \mathrm{mg} / \mathrm{gm}(\mathrm{P}<0.01)$ in group $-2,0.3 \pm 0.05$ $\mathrm{mg} / \mathrm{gm} \quad(\mathrm{P}<0.01)$ in group- $3,0.38 \pm 0.002$ $\mathrm{mg} / \mathrm{gm}(\mathrm{P}<0.01)$ in group-4, and $0.22 \pm 0.003$ $\mathrm{mg} / \mathrm{gm}(\mathrm{P}<0.01)$ in group-5. It is observed that the sodium content in bones of experimental 
chick group-3 and group-4 was higher than that of all other groups. It was lowest in chicks fed with white grains and higher than this, but nearly equal in chicks fed with commercial food and fish meal as additive. So it is observed that the sodium content was comparatively higher in both groups of chicks fed with $10 \%$ and $20 \%$ addition of molluscan feed.

The potassium contents in bones of experimental birds was $0.31 \pm 0.002(\mathrm{mg} / \mathrm{gm})$ in group- $1,0.41 \pm 0.003 \mathrm{mg} / \mathrm{gm}(\mathrm{P}<0.01)$ in group-
2, $0.37 \pm 0.0016 \mathrm{mg} / \mathrm{gm}(\mathrm{P}<0.01)$ in group-3, $0.28 \pm 0.0016 \mathrm{mg} / \mathrm{gm}(\mathrm{P}<0.01)$ in group -4 , and $0.41 \pm 0.0016 \mathrm{mg} / \mathrm{gm}(\mathrm{P}<0.01)$ in group -5 . These results revealed that the potassium content in bone of poultry birds varied in all the groups. It was lowest in chicks fed with $20 \%$ molluscan feed. It was observed that there was higher and equal content of potassium in bones of chicks fed with $10 \%$ molluscan feed, recognized poultry feed and fish meal feed compared to white grain fed chicks.

Table. 1- Mineral contents in Bones of Chicks

\begin{tabular}{|l|l|l|l|l|l|}
\hline $\begin{array}{l}\text { Estimated } \\
\text { Elements }\end{array}$ & $\begin{array}{l}\text { S-1 } \\
\text { (Control) }\end{array}$ & $\begin{array}{l}\text { S-2 } \\
\text { (Poultry Farm } \\
\text { recognized } \\
\text { food) }\end{array}$ & $\begin{array}{l}\text { S-3 } \\
\text { (Exp-I } \\
10 \%)\end{array}$ & $\begin{array}{l}\text { S-4 } \\
\text { (Exp-II } \\
20 \%)\end{array}$ & $\begin{array}{l}\text { S-5 } \\
\text { (Fish Meal) }\end{array}$ \\
\hline \multirow{2}{*}{ Phosphorus (P) $(\mathrm{mg} / \mathrm{gm})$} & $0.07 \pm$ & $0.14^{*} \pm$ & $0.1^{*} \pm$ & $0.15^{*} \pm$ & $0.01^{*} \pm$ \\
& 0.0018 & 0.002 & 0.0015 & 0.004 & 0.003 \\
\hline \multirow{2}{*}{ Sodium $(\mathrm{Na})(\mathrm{mg} / \mathrm{gm})$} & $0.1 \pm$ & $0.21^{*} \pm$ & $0.3^{*} \pm$ & $0.38^{*} \pm$ & $0.22^{*} \pm$ \\
& 0.0012 & 0.002 & 0.052 & 0.002 & 0.003 \\
\hline Potassium $(\mathrm{K})(\mathrm{mg} / \mathrm{gm})$ & $0.31 \pm$ & $0.41^{*} \pm$ & $0.37^{*} \pm$ & $0.28^{*} \pm$ & $0.41^{*} \pm$ \\
& 0.002 & 0.003 & 0.0016 & 0.0016 & 0.0016 \\
\hline Calcium $(\mathrm{Ca})(\mathrm{mg} / \mathrm{gm})$ & $0.03 \pm$ & $0.06^{*} \pm$ & $0.07^{*} \pm$ & $0.1^{*} \pm$ & $0.03^{\mathrm{NS}} \pm$ \\
& 0.003 & 0.002 & 0.003 & 0.003 & 0.003 \\
\hline
\end{tabular}

-Values are mean $\pm \mathrm{SD} ; \mathrm{n}=5$, Degrees of freedom $=4, * \mathbf{P}<\mathbf{0 . 0 1}$ (Highly Significant),

** $\mathbf{P}<0.05$ (Significant), NS- Not Significant. ( significance is compared with control group)

\section{Conclusion:}

It would be useful to look at the effects of the present raw materials over a longer period and to determine the actual nutritive contribution of the bivalve mollusc. The addition of molluscan flesh and shell crush to chick diets at a level of $10 \%$ or $20 \%$ did not negatively affect in chick performance, weight gain, bone strength, pathological or physiological changes. This result also indicates that additional molluscan diet did not negatively affect other dietary nutrients.

\section{References:}

Almeida Paz, I.C.L., and L.D.G. Bruno, (2006): Bone mineral density: review. Braz. J. Poult. Sci., 8(2): pp. 69-73.

Aziz-Abdul, T. A., (1998): Cage layer fatigue is a complicated problem. World's Poult. Sci. J., 14: pp. 56-58.

Dell'Isola, A.T.P., J.A.F. Veloso, N.C. Baiao and S.L. Medeiros, (2003): Efeito do oleo de soja em dietas com diferentes niveis de calcio sobre a absorçao e retençao óssea de calcio e de fosforo em frangos de corte. Arq. Bras. Med. Vet. Zootec., 55: pp. 461-466.

Duff, S. R., R. B. Burns, and P. Dwivedi, (1987): Skeletal changes in broiler chicks and turkey poults fed diets containing ochratoxin A. Res. Vet. Sci., 43: pp. 301-307.
Edwards, H.M. Jr., and J.R. Veltmann, Jr., (1983): The role of calcium and phosphorus in the etiology of tibial dyschondroplasia in young chicks. J. Nutr., 113: pp. 1568-15

Heany, R. P., (1998): Excess dietary protein may not adversely affect bone. J. Nutr., 128: pp. 1054-1057.

Heuser, G. F., (1952): Salt Additions to Chick Rations. Poult. Sci., 31: pp. 85.

Huff, w. E., J. A. Doerr, P. B. Hamilton, D. D. Hamann, P. E. Peterson, and A. Ciegler, (1980): Evaluation of bone strength during aflatoxicosis and ochratoxicosis. Appl. Microbiol., 40: pp. 102-107.

Korver, D.R., J.L. Saunders-Blades, and K.L. Nadeau, (2004). Assessing bone mineral density in vivo quantitative computed technology. Poult. Sci., 83: pp. 222-229.

Kumpost, H. E. and T. W. Sullivan, (1966): Minimum Sodium Requirement and Interaction of Potassium and Sodium in the diet of Young Turkeys. Poult. Sci., 45: pp. 1334.

Lilburn, M. S., (1994): Skeletal growth of commercial poultry species. Poult. Sci., 73: pp. 897-903.

McWard, G. W. and H. M. Scott, (1961). Sodium Requirements of the Young Chick Fed Purified Diets. Poult. Sci., 40: pp. 1026. 
Maurice, D. V., A. B. Bodine, and N. J. Rehrer, (1983): Metabolic effects of low aflatoxin B1 on broiler chickens. Appl. Environ. Microbiol., 45: pp. 980-984.

National Research Council [NRC], (1994): Nutrient Requirements of Poultry, 9th Revised Edition, 1994. National Research Council, Board on Agriculture, Committee on Animal Nutrition, Subcommittee on Poultry Nutrition. National Academic Press, Washington, DC.

Onyango, E.M., P.Y. Hester, R Stroshine and O. Adeola, (2003): Bone densitometry as an indicator of percentage tibia ash in broiler chicks fed varying dietary calcium and phosphorus levels. Poult. Sci., 82: pp. 17871791.

Perry, R. W., G. N. Rowland, T. L. Foutz, and J. R. Glisson, (1991): Poult malabsorption syndrome. III. Skeletal lesions in market age turkeys. Avian Dis., 35: pp. 707-713.

Pizauro Junior, J.M., (2002): Hormonios e regulacao dotecido osseo. In: Macari, M., Furlan, R.L., Gonzales, E. (Eds.), Fisiologia aviaria aplicada a frangos de corte. FUNEP/UNESP, Jaboticabal, pp. 260-273.

Rosenfield, D.J.; A.G. Germat.; J.D. Marcono; J.P. Murill.; G.H. Lopez; J.A. Flores: 1997 The effect of using different levels of shrimp meals in broiler diets. Poult.Sci.,76 (4):581-588

Schreiweis, M. A., J. I. Orban, M. C. Ledur, and P. Y. Hester, (2003a): The use of densitometry to detect differences in bone mineral density and content of live White Leghorns fed varying levels of dietary calcium. Poult. Sci., 82: pp. 1292-1301

Seigel, R. C., and J. C. Fu, (1976). Collagen cross linking. Purification and substrate specificity of lysyl oxidase. J. Biol. Chem., 18: pp. 5779-5785.

Sudharmai Devi, C.R., (2004): Analytical Procedures in Soil Science and Agricultural Chemistry, for Analysis of Organic Manure. (ed.), pp. 138-139.

Wohl, G. R., L. Loehrke, B. A. Watkins, and R. F. Zernicke, (1998): Effects of high fat diet on mature bone mineral content, structure, and mechanical properties. Calcif. Tiss. Int., 63: pp. 74-79.

Ziaei, N., H. Kermanshahi, and M. Pile Var, (2010): Effects of dietary crude protein and mineral content on growth performance, and tibia bone parameters in brouler chicken during starter period. A review for XIIIth European Poultry Conference. pp. 01-04. 